\title{
ANALYSIS OF THE RESULTS OF THE INITIAL STAGE OF THE PROGRAM OF PSYCHOLOGICAL SUPPORT OF COMBATIANS AND THEIR FAMILIES
}

\section{АНАЛІЗ РЕЗУЛЬТАТІВ ПРОВЕДЕННЯ ПОЧАТКОВОГО ЕТАПУ ПРОГРАМИ ПСИХОЛОГІЧНОГО СУПРОВОДУ КОМБАТАНТІВ ТА ЇХ СІМЕЙ}

\section{Roman Popeliushko}

DOI: https://doi.org/10.30525/978-9934-26-049-0-27

Abstract. The article emphasizes that Ukrainian society is suffering from the effects of the war in the east of the country. These consequences are manifested both in the direct participants in the hostilities and in their family members, who have been in a state of stress for a long time, waiting for the disappointing news from the east about their relatives and friends. It is noted that while participating in hostilities, many combatants receive combat mental injuries. These injuries further lead to post-traumatic stress disorder and other psychosomatic disorders that cause his psychosocial self-isolation, disruption of relationships with family and self-destructive behavior that leads to premature death.

An urgent and urgent problem of today's Ukrainian state is the organization of effective social and psychological rehabilitation of combatants and their families. But at the moment, Ukraine has not created a single comprehensive program of social and psychological rehabilitation of combatants and their families.

Therefore, the aim of the article is to analyze the initial diagnostic indicators of psychological trauma of combatants who took part in our proposed program of psychological support of combatants and their families, at the initial, first stage of this program. The methodological bases of the work were such general scientific and special methods as: method of analysis and generalization of psychodiagnostic indicators, formal-logical method, psychological and clinical methods and tests.

\footnotetext{
${ }^{1}$ Candidate of Psychological Sciences, Associate Professor, National Pedagogical Dragomanov University, Ukraine

(C) Roman Popeliushko
} 
This paper briefly considers the purpose, main tasks and structural components of the proposed program of psychological support of combatants and their families. The main focus of the work is focused on the first (diagnostic) phase of the program. The purpose of this stage was to carry out a psychological diagnosis of the long-term effects of stressors in combatants. The implementation of the diagnostic stage was carried out during 2018, on the basis of military units, recreational facilities, social, volunteer and rehabilitation centers, etc. The total number of combatants covered by the study was 356 people.

It is emphasized that for the experimental study of long-term effects of stressors in combatants, a proven set of clinical-psychopathological and psychodiagnostic techniques was proposed to study 5 factors that have become key in building a system of psychological rehabilitation of combatants. These factors included: the presence of signs of post-traumatic stress disorder; the presence of signs of stress; the presence of signs of anxiety; the presence of signs of depression; and combat experience of the combatant.

Analysis of the results of the first stage of the program of psychological support combatants noted the presence of a large number of subjects, such phenomena as post-traumatic stress disorder (more than $60 \%$ of combatants), stress (more than $45 \%$ of combatants), anxiety (more than $35 \%$ of combatants), depression (more than $30 \%$ of combatants).

Also drawn attention to the fact that the findings confirm the results of previous studies of domestic and foreign researchers and practitioners that some of the combatants who participated in the fighting eventually begin to suffer from long-term effects of stress effects. Therefore, further implementation of the program of psychological support of combatants, with long-term effects of stress, and their families, on the basis of genetic-psychological-axiological approach, namely the second stage, which provides psychological and social assistance or support to combatants and their families, is a promising and effective means of their psychological rehabilitation.

\section{1. Ветуп}

Сучасне українське суспільство потерпає від наслідків війни на сході нашої держави. Ці наслідки проявляються як у безпосередніх учасників бойових дій, так і у членів їх сімей, які тривалий час перебували у стресовому стані, очікуючи невтішних новин зі сходу про своїх рідних і 
близьких. Також не слід забувати про тимчасово переміщених осіб, які також зазнали впливу незвичної для них, травматичної ситуації.

Велика кількість комбатантів, учасників бойових дій, в наслідок участі у військових діях отримали бойові психічні травми. Ці травми, в перспективі призводять до виникнення посттравматичного стресового розладу та інших психосоматичних порушень. Наявність такого комплексу порушень у комбатанта, учасника бойових дій, спричиняє його психосоціальну самоізольованість, порушення взаємостосунків з родиною та нерідко і ауто деструктивну поведінку, яка призводить до передчасної смерті.

Актуальність дослідження. Проблема психофізичного здоров'я військового, учасника бойових дій, актуальна не тільки для комбатантів та їх сімей а і для держави в цілому. Оскільки, комбатант працездатного віку з порушеним психофізичним здоров'ям, є додатковим навантаженням на сферу соціальних послуг, медицину та інші сфери нашої держави. Тому організація ефективної соціально-психологічної реабілітації комбатантів, учасників бойових дій, та їх сімей $є$ невідкладною проблемою сьогодення української держави.

Нажаль, на даний момент, в нашій державі не створено єдиної програми соціально-психологічної реабілітації комбатантів та їх сімей. Робляться спроби на регіональному рівні, запровадити різноманітні програми реабілітації військових, але вони часто ініціюються громадськими організаціями та спілками ветеранів АТО-ООС, що в свою чергу говорить про їх мультивекторність (по методиці проведення та по впливу на діапазон психологічних якостей, порушень та наслідків для комбатантів) та відсутність загальної координації на державному рівні.

Метою дослідження $є$ аналіз вихідних діагностичних показників психологічної травматизації комбатантів, учасників бойових дій, які приймали участь у програмі психологічного супроводу комбатантів та їх сімей, на початковому, першому етапі даної програми.

Методологічною основою роботи стали такі загальнонаукові та спеціальні методи, як: метод аналізу та узагальнення психодіагностичних показників, формально-логічний метод. Також у дослідженні використовувалися такі психологічні та клінічні методики, як: методика «Місіссіпська шкала для оцінки посттравматичних реакцій», шкала самооцінки наявності ПТСР, шкала «РSM-25», тест «Аналіз стилю життя», методика «Шкала реактивної та особистісної тривож- 
ності Спілберга-Ханіна», шкала тривоги Бека, опитувальник депресивності А.Т. Бека, шкала депресивності Цунга, методика «Шкала оцінки інтенсивності бойового досвіду», методика визначення каналів психологічних ресурсів BASIC Ph.

Запропонована нами програма психологічного супроводу комбатантів, учасників бойових дій, буде значно ефективнішою, якщо до неї включити соціально-психологічну роботу і з сім'ями, цих комбатантів. Програма психологічного супроводу реалізовувалася як у реабілітаційних центрах, так і за місцем проживання сім'ї комбатанта.

Метою програми психологічного супроводу комбатантів 3 віддаленими наслідками стресогенних впливів, та їх сімей, було:

- позбавлення від симптомів посттравматичного стресового розладу;

- досягнення емоційного і психофізіологічного здоров'я;

- зміна взаємовідносин з навколишнім світом.

Мета програми є нероздільною, оскільки, досягнення якого-небудь одного компонента мети, неможливе без досягнення всіх інших.

Завдання програми полягало у розробці та реалізації спеціальних соціально-психологічних заходів, які включали завдання і вправи для:

- корекції та формуванням стресостійкості і адекватності самооцінки комбатантів;

- зниження тривожності та конфліктності в учасників бойових дій та членів їх сімей;

- підвищення комунікативних вмінь;

- нормалізації психофізіологічних станів комбатантів.

Дана програма психологічного супроводу комбатантів та їх сімей, перед-бачала здійснення таких етапів, як:

1-й етап. Початковий (діагностика).

Мета початкового етапу програми психологічного супроводу полягала у психологічній діагностиці віддалених наслідків стресогенних впливів у комбатантів. Даний етап передбачає такі види роботи, як:

a) діагностика віддалених наслідків стресогенних впливів у комбатантів (ПТСР, стрес, тривожність, депресія, рівень бойового досвіду, канали психологічного ресурсу);

б) встановлення позитивного контакту психолога 3 комбатантом, шляхом взаємної адаптації та роз'яснення особливостей проведення даної програми. 
2-й етап. Надання психолого-соціальної допомоги або підтримки комбатантам та їх сім'ям.

Meта цього етапу програми психологічного супроводу полягала у здійс-ненні заходів по реадаптації та реабілітації комбатантів з віддаленими наслідками стресогенних впливів та їх сімей.

Цей етап програми передбачав такі види роботи, як:

a) індивідуальні та сімейні консультації (індивідуальні консультації; робота з захисними механізмами та ціннісними орієнтаціями комбатантів; обговорення цілей та мети програми супроводу; освіта та самоосвіта комбатантів та їх сімей; формування позитивної самооцінки);

б) групова психокорекція (амбулаторна програма психологічної реабілітації; тренінгова робота; проведення конференцій, круглих столів; освітні лекційні заняття);

в) залучення до суспільно-корисної діяльності (проведення тематичних зустрічей з комбатантами; організація культурно-масових заходів; підтримка громадських організацій).

Третій «Завершальний» етап програми психологічного супроводу передбачав здійснення повторної діагностики, за допомогою адаптованого клініко-психологічного комплексу діагностичних методик (застосовувались діагностичні методики тіж самі, що і на першому етапі), віддалених наслідків стресогенних впливів у комбатантів контрольної та експериментальної груп, та здійснення аналізу результативності впровадженої програми психологічного супроводу.

Виходячи 3 мети, завдань та етапів програми психологічного супроводу комбатантів 3 віддаленими наслідками стресогенних впливів та їх сімей, було розпочато реалізацію даної програми. Реалізація програми психологічного супроводу здійснювалась протягом 2018-2019 років, на базі військових частин, рекреаційних установ, соціальних, волонтерських та реабілітаційних центрів тощо. Загальна кількість комбатантів які були охопленні даною програмою, склала 356 чоловік.

Перший «Початковий» етап програми психологічного супроводу, передбачав діагностику віддалених наслідків стресогенних впливів у комбатантів та встановлення позитивного контакту з комбатантами, які брали участь у програмі супроводу. 
Для експериментального дослідження віддалених наслідків стресогенних впливів у комбатантів, нами було запропоновано апробований комплекс клініко-психопатологічних і психодіагностичних методик спрямований на дослідження 5 факторів, які на нашу думку, стали основними при побудові системи психологічної реабілітації комбатантів. До цих факторів було віднесено: наявність ознак посттравматичного стресового розладу; наявність ознак стресу; наявність ознак тривожності; наявність ознак депресії; та бойовий досвід комбатанта.

Для реалізації першого етапу програми психологічного супроводу було проведено діагностичне дослідження за такими психодіагностичними методиками як: Міссісіпська шкала посттравматичного стресового розладу (військовий варіант) [4]; шкала самооцінки наявності посттравматичного стресового розладу (PTSD Check List Military Version «PCL-M») [9]; шкала психологічного стресу RSM-25. Шкала PSM-25 Лемура-Тесье-Філліон [2]; тест «Аналіз стилю життя» (Бостонський тест на стресостійкість) [6]; шкала реактивної та особистісної тривожності (Ч.Д. Спілберга - Ю.Л. Ханіна) [3]; шкала тривоги Бека (The Beck Anxiety Inventory - BAI) [8]; опитувальник депресивності Бека (Beck Depression Inventory - BDI) [4]; шкала самооцінки рівня депресії Цунга (Z-SDS) [5]; шкала оцінки інтенсивності бойового досвіду [1].

Також була застосована багатовимірна модель BASIC Ph [7], для дослідження стратегій поведінки комбатантів у психотравмуючих ситуаціях, як одного з ресурсів в процесі їх психологічної реабілітації.

Дослідження проводилось протягом 2018 року, респондентами виступили комбатанти які ще продовжували службу у збройних силах і ті, що вже пішли у запас, у кількості 356 чоловік. Для перевірки результативності програми супроводу, дані комбатанти були об'єднанні у експериментальну (221 чоловік) та контрольну (135 чоловік) групи. Значну частину респондентів експериментальної групи складали комбатанти, учасники бойових дій, звільнені у запас, а контрольна група в більшості складалася $з$ дійсних військовослужбових, які направлялися в зону проведення бойових дій згідно ротаційного графіку. 


\section{2. Аналіз наявності ознак посттравматичного стресового розладу у комбатантів}

На основі проведеної «Міссісіпської шкали для оцінки посттравматичних реакцій», ми мали змогу виявити та оцінити прояви посттравматичного стресового розладу (симптоми вторгнення, уникнення, фізіологічної збудливості, почуття провини і суїцидальності) у комбатантів. При діагностиці було виявлено наступні результати: в експериментальній групі посттравматичний стресовий розлад виявлений у 28,1\% досліджуваних, характерні для посттравматичного розладу ознаки прослідковувалися у 44,6\% комбатантів, добре адаптованими були 27,3\% досліджуваних.

В контрольній групі комбатантів, були виявленні наступні діагностичні результати: посттравматичний стресовий розлад виявлений у 23,2\% досліджуваних, характерні для посттравматичного розладу ознаки прослідковувалися у 41,7\% комбатантів, добре адаптованими були $35,1 \%$ досліджуваних.

Отримані результати дослідження комбатантів експериментальної та контрольної груп представлено у таблиці 1.

Таблиця 1

\section{Результати дослідження у комбатантів}

за методикою «Міссісіпська шкала для оцінки посттравматичних реакцій» в експериментальній та контрольній групах

\begin{tabular}{|l|c|c|}
\hline \multicolumn{1}{|c|}{ Показники (рівні) } & $\begin{array}{c}\text { Експериментальна } \\
\text { група (n-221) }\end{array}$ & $\begin{array}{c}\text { Контрольна група } \\
\text { (n-135) }\end{array}$ \\
\hline ПТСР & $28,1 \%$ & $23,2 \%$ \\
\hline Характерні для ПТСР розлади & $44,6 \%$ & $41,7 \%$ \\
\hline Добре адаптовані & $27,3 \%$ & $35,1 \%$ \\
\hline
\end{tabular}

На основі проведеної шкали «Самооцінка наявності посттравматичного стресового розладу» (PTSD CheckList - Military Version), ми мали змогу виявити ознаки ПТСР, у комбатантів за діагностичними критеріями DSM-IV. Аналіз даних дослідження виявив такі результати: в експериментальній групі нормативні показники психічної активності виявлено у 29,3\% осіб, окремі ознаки посттравматичного стресового розладу спостерігалися у $38,6 \%$ досліджуваних, наяв- 
ність посттравматичного стресового розладу простежувалася лише у $32,1 \%$ комбатантів.

В контрольній групі нормативні показники психічної активності виявлено у $32,2 \%$ осіб, окремі ознаки посттравматичного стресового розладу спостерігалися у 39,6\% досліджуваних, наявність посттравматичного стресового розладу простежувалися тільки у $28,2 \%$ комбатантів.

Отримані результати дослідження комбатантів експериментальної та контрольної груп представлено у таблиці 2.

Таблиця 2

\section{Результати дослідження у комбатантів за методикою «Самооцінка наявності ПТСР» в експериментальній та контрольній групах}

\begin{tabular}{|l|c|c|}
\hline \multicolumn{1}{|c|}{ Показники (рівні) } & $\begin{array}{c}\text { Експериментальна } \\
\text { група (n-221) }\end{array}$ & $\begin{array}{c}\text { Контрольна група } \\
\text { (n-135) }\end{array}$ \\
\hline Наявність ПТСР & $32,1 \%$ & $28,2 \%$ \\
\hline Окремі симптоми ПТСР & $38,6 \%$ & $39,6 \%$ \\
\hline Нормативні показники & $29,3 \%$ & $32,2 \%$ \\
\hline
\end{tabular}

Результати двох клініко-психологічних діагностичних методик свідчать про те, що у значної кількості досліджуваних комбатантів присутній посттравматичний стресовий розлад чи його явні прояви. Також, ми можемо констатувати, що дані результати демонструють практично схожі показники, але результати контрольної групи дещо нижчі. Цей факт, на нашу думку, можна пояснити тим, що більшість комбатантів контрольної групи ще перебувають на військовій службі (яка передбачає постійну ментальну і фізичну зайнятість з моральнофізичної підготовки у військових частинах та виконання своїх службових обов'язків у зоні проведення АТО-ООС) і ще не відчувають повної сили віддалених наслідків стресогенних впливів.

\section{3. Аналіз наявності ознак стресових відчуттів та стресостійкості у комбатантів}

Для вимірювання феноменологічної структури переживань стресу, нами була використана методика «Шкала PSM-25 Лемура-ТесьеФілліон». На основі цієї методики ми визначили рівень стресових 
відчуттів в соматичних, поведінкових і емоційних показниках у комбатантів. В результаті дослідження було констатовано наступні результати: в експериментальній групі низький рівень стресових відчуттів був виявлений у $36,7 \%$ осіб, середній рівень стресових відчуттів спостерігався у 23,1\% досліджуваних, а високий рівень стресових відчуттів був констатований у 40,2\% комбатантів.

В контрольній групі комбатантів, низький рівень стресових відчуттів був виявлений у $43,2 \%$ осіб, середній рівень стресових відчуттів спостерігався у 26,2\% досліджуваних, а високий рівень стресових відчуттів був констатований у $30,6 \%$ комбатантів.

Отримані результати дослідження комбатантів експериментальної та контрольної груп представлено у таблиці 3.

Таблиця 3

Результати дослідження рівня стресових відчуттів у комбатантів за шкалою PSM-25 в експериментальній та контрольній групах

\begin{tabular}{|c|c|c|}
\hline $\begin{array}{c}\text { Рівень стресових } \\
\text { відчуттів }\end{array}$ & $\begin{array}{c}\text { Експериментальна } \\
\text { група (n-221) }\end{array}$ & $\begin{array}{c}\text { Контрольна група } \\
\text { (n-135) }\end{array}$ \\
\hline Високий & $40,2 \%$ & $30,6 \%$ \\
\hline Середній & $23,1 \%$ & $26,2 \%$ \\
\hline Низький & $36,7 \%$ & $43,2 \%$ \\
\hline
\end{tabular}

Діагностичне дослідження феноменологічної структури переживань стресу, свідчить про те, що у комбатантів спостерігалися такі стани, як: дратівливість, тривожність та неуважність. Також, доволі часто у них виникав необгрунтований гнів. Комбатанти скаржились на забудькуватість, швидку втому, проблеми зі сном, головні болі, скачки тиску та інші соматичні та психологічні проблеми.

Результати проведеного тесту «Аналіз стилю життя» (Бостонський тест на стресостійкість), дали змогу визначити рівень стресостійкості особистості комбатанта. Дані результати виявили наступні показники: в експериментальній групі гарна стійкість до стресових ситуацій простежувалася у 9,1\% досліджуваних, рівень вище за середній був виявлений у $35,6 \%$ комбатантів, середній рівень стресостійкості особистості спостерігається у $32,2 \%$ осіб, погану стійкість до стресових ситуацій виявили у 23,1\% досліджуваних. 
В контрольній групі гарна стійкість до стресових ситуацій простежувалася у 11,3\% досліджуваних, рівень вище за середній був виявлений у $31,5 \%$ комбатантів, натомість середній рівень стресостійкості особистості спостерігається у $35,1 \%$ осіб, а погану стійкість до стресових ситуацій було виявлено у $22,1 \%$ досліджуваних.

Отримані результати дослідження комбатантів експериментальної та контрольної груп представлено у таблиці 4.

Таблиця 4

Результати дослідження рівня стресостійкості у комбатантів за тестом «Аналіз стилю життя» в експериментальній та контрольній групах

\begin{tabular}{|c|c|c|}
\hline $\begin{array}{c}\text { Рівень стресостійкості } \\
\text { особистості }\end{array}$ & $\begin{array}{c}\text { Експериментальна } \\
\text { група (n-221) }\end{array}$ & $\begin{array}{c}\text { Контрольна група } \\
\text { (n-135) }\end{array}$ \\
\hline Високий & $9,1 \%$ & $11,3 \%$ \\
\hline Вище середнього & $35,6 \%$ & $31,5 \%$ \\
\hline Середній & $32,2 \%$ & $35,1 \%$ \\
\hline Низький & $23,1 \%$ & $22,1 \%$ \\
\hline
\end{tabular}

Дані результати засвідчують, що практично половина всіх досліджуваних комбатантів, учасників бойових дій, мають середній та високий рівень стресових відчуттів. Тому, наявність даних рівнів констатує у досліджуваних комбатантів, присутність труднощів як на психологічному так і на фізіологічному рівнях, що в подальшому, якщо не застосувати комплексну програму по зниженню стресових відчуттів, призведе до емоційних і фізичних зривів та стрімкого погіршення взаємостосунків з оточуючими.

\section{4. Аналіз наявності ознак реактивної та особистісної тривожності і вираженості тривожних розладів у комбатантів}

На основі проведеної методики «Шкала реактивної та особистісної тривожності Ч.Д. Спілберга - Ю.Л. Ханіна» ми мали змогу визначити рівень ситуативної (тривожність як стан) та особистісної (тривожність як диспозиція) тривожності комбатантів. Результати діагностики констатували наступні показники: в експериментальній групі низька ситуативна тривожність була виявлена у $28,2 \%$ досліджуваних, 
помірна ситуативна тривожність спостерігалася у 40,7\% респондентів, а висока ситуативна тривожність простежувалася у $31,1 \%$ комбатантів; показники низької особистісної тривожності спостерігались у $32,1 \%$ досліджуваних, помірна особистісна тривожність простежувалася у 33,8\% комбатантів, а показники високої особистісної тривожності були виявленні у 34,1\% досліджуваних респондентів.

В контрольній групі комбатантів, низька ситуативна тривожність була виявлена у $31,3 \%$ досліджуваних, помірна ситуативна тривожність спостерігалася у 39,6\% осіб, а висока ситуативна тривожність простежувалася у 29,1\% комбатантів; показники низької особистісної тривожності спостерігалися у $35,6 \%$ досліджуваних, помірна особистісна тривожність простежувалася у 34,2\% комбатантів, а показники високої особистісної тривожності були виявленні у $30,2 \%$ респондентів.

Отримані результати дослідження комбатантів експериментальної та контрольної груп представлено у таблиці 5.

Таблиця 5

Результати дослідження комбатантів за «Шкалою визначення рівня ситуативної та особистісної тривожності СпілбергераХаніна» в експериментальній та контрольній групах

\begin{tabular}{|c|c|c|c|c|}
\hline \multirow{2}{*}{ Рівень } & \multicolumn{2}{|c|}{ Експериментальна група (n-221) } & \multicolumn{2}{|c|}{ Контрольна група (n-135) } \\
\cline { 2 - 5 } & $\begin{array}{c}\text { Ситуативна } \\
\text { тривожність }\end{array}$ & $\begin{array}{c}\text { Особистісна } \\
\text { тривожність }\end{array}$ & $\begin{array}{c}\text { Ситуативна } \\
\text { тривожність }\end{array}$ & $\begin{array}{c}\text { Особистісна } \\
\text { тривожність }\end{array}$ \\
\hline Високий & $31,1 \%$ & $34,1 \%$ & $29,1 \%$ & $30,2 \%$ \\
\hline Середній & $40,7 \%$ & $33,8 \%$ & $39,6 \%$ & $34,2 \%$ \\
\hline Низький & $28,2 \%$ & $32,1 \%$ & $31,3 \%$ & $35,6 \%$ \\
\hline
\end{tabular}

Отримані експериментальні результати засвідчують те, що у достатньо великої кількості комбатантів, учасників бойових дій, спостерігався доволі високий відсоток високого рівня ситуативної та особистісної тривожності. Це в свою чергу засвідчує, наявність у комбатантів прихованих та відкритих невротичних внутрішньо особистісних і міжособистісних конфліктів, з емоційними і невротичними зривами.

Результати дослідження ступеня вираженості тривожних розладів у комбатантів, за клінічною тестовою методикою «Шкала тривоги 
Бека» (The Beck Anxiety Inventory - BAI), констатували наступні показники: в експериментальній групі незначний рівень тривоги був виявлений у 42,7\% досліджуваних осіб, середня вираженість тривоги простежувалася у $37,1 \%$ комбатантів, а дуже високий рівень тривоги спостерігався у $20,2 \%$ респондентів.

В контрольній групі комбатантів, показники незначного рівня тривоги були виявлені у 44,5\% досліджуваних осіб, середня вираженість тривоги простежувалася у 39,2\% комбатантів, а дуже високий рівень тривоги спостерігався у $16,3 \%$ респондентів.

Результати дослідження комбатантів експериментальної та контрольної груп представлено у таблиці 6.

Таблиця 6

Результати дослідження за методикою «Шкала тривоги Бека» у комбатантів в експериментальній та контрольній групах

\begin{tabular}{|c|c|c|}
\hline Рівень & $\begin{array}{c}\text { Експериментальна } \\
\text { група (n-221) }\end{array}$ & $\begin{array}{c}\text { Контрольна група } \\
\text { (n-135) }\end{array}$ \\
\hline Високий рівень & $20,2 \%$ & $16,3 \%$ \\
\hline Середній рівень & $37,1 \%$ & $39,2 \%$ \\
\hline Незначний рівень & $42,7 \%$ & $44,5 \%$ \\
\hline
\end{tabular}

Діагностичне дослідження показало, що існувала велика кількість комбатантів у яких стан тривожності простежувався на середньому та високому рівні. Дані результати констатують наявність у комбатантів, таких психологічних особливостей, як: відчуття напруги, заклопотаності, неспокою, нервозністю, невизначеності, безсилля, незахищеності, невдачі, самотності, неможливості без сторонньої допомоги ухвалювати рішення. На фізіологічному рівні, у комбатантів спостерігалися: посилення серцебиття, почастішання дихання, збільшення хвилинного об'єму циркуляції крові, підвищення артеріального тиску, зростання загальної збудливості, зниження порогів чутливості.

Виходячи з цих показників, існує нагальна потреба в застосуванні, до комбатантів, активностей по зниженню рівнів тривожності, засобами релаксації, арт-терапії, аутотренінгів та ін., що призведе до нормалізації як психічного та і фізіологічного самопочуття. 


\section{5. Аналіз наявності ознак депресії та інтенсивності} депресивних симптомів у комбатантів

На основі проведеного клініко-психологічного опитувальника депресивності А.Т. Бека (Beck Depression Inventory - BDI) ми мали змогу визначити наявність депресії і ступінь важкості депресивних розладів у комбатантів. Кількісний аналіз продемонстрував такі результати: в експериментальній групі відсутність депресивних симптомів простежувалася у 42,6\% досліджуваних осіб, помірно виражена депресія спостерігалася у $31,2 \%$ комбатантів, критичний рівень депресії виявився у 19,1\% респондентів, а явно виражена депресивна симптоматика спостерігалася лише у 7,1\% комбатантів.

В контрольній групі комбатантів, відсутність депресивних симптомів простежувалася у 41,5\% досліджуваних осіб, помірно виражена депресія спостерігалася у $36,1 \%$ комбатантів, критичний рівень депресії був виявлений у 17,1\% військовослужбовців, а явно виражена депресивна симптоматика спостерігалася у 5,3\% комбатантів.

Отримані результати дослідження комбатантів експериментальної та контрольної груп представлено у таблиці 7.

Таблиця 7

Результати дослідження за методикою «Шкала депресії А.Т. Бека» у комбатантів в експериментальній та контрольній групах

\begin{tabular}{|l|c|c|}
\hline \multicolumn{1}{|c|}{ Рівень } & $\begin{array}{c}\text { Експериментальна } \\
\text { група (n-221) }\end{array}$ & $\begin{array}{c}\text { Контрольна } \\
\text { група (n-135) }\end{array}$ \\
\hline Відсутність депресивних симптомів & $42,6 \%$ & $41,5 \%$ \\
\hline Помірно виражена депресія & $31,2 \%$ & $36,1 \%$ \\
\hline Критичний рівень депресії & $19,1 \%$ & $17,1 \%$ \\
\hline Явно виражена депресивна симптоматика & $7,1 \%$ & $5,3 \%$ \\
\hline
\end{tabular}

Якісний аналіз дозволив нам зробити висновок про те, що було виявле-но велику кількість комбатантів, учасників бойових дій, з ознаками депресії. В контрольній та експериментальній групах комбатантів, 3 різною силою та якістю проявлялися такі симптоми, як: роздратованість, печаль, придушення власних негативних емоцій, втрата апетиту, песимізм, відчуття незадоволеності собою, відчуття невезіння, самозаперечення, почуття провини, відчуття покарання, самозвинувачення, 
нерішучість, почуття соціальної відчуженості, порушення сну, фізична і психічна втома, суїцидальні думки, втрата ваги, труднощі у професійній діяльності, занепокоєння станом власного здоров'я, втрата сексуального потягу, зловживання алкоголем, тютюном, сильнодіючими медикаментозними засобами.

Тому застосування до цих комбатантів заходів психологічної реабілітації $є$ вкрай важливим чинником їхнього повернення до норм психічного здоров'я та налагодження чи відновлення соціальних комунікацій, як з власною родиною так із побратимами та колегами по роботі.

Діагностичні результати проведеного дослідження за шкалою Цунга (Z-SDS), дали нам можливість виявити особливості самооцінки депресії та інтенсивність депресивних симптомів у комбатантів. Отримані результати діагностичного дослідження засвідчують, що в експериментальній групі без депресивний стан простежувався у 48,7\% досліджуваних осіб, легка депресія, ситуативного чи невротичного генезу спостерігалася у $38,1 \%$ комбатантів, а присутність явно вираженої депресивної симптоматики було виявлено у 13,2\% досліджуваних осіб.

В контрольній групі без депресивний стан простежувався у $50,8 \%$ досліджуваних осіб, легка депресія ситуативного чи невротичного генезу спостерігалася у 37,1\% комбатантів, а присутність явно вираженої депресивної симптоматики було виявлено у 12,1\% досліджуваних осіб.

Отримані результати дослідження комбатантів експериментальної та контрольної груп представлено у таблиці 8.

Таблиця 8

\section{Результати дослідження самооцінки депресії за шкалою Цунга} у комбатантів в експериментальній та контрольній групах

\begin{tabular}{|l|c|c|}
\hline \multicolumn{1}{|c|}{ Рівень } & $\begin{array}{c}\text { Експериментальна } \\
\text { група (n-221) }\end{array}$ & $\begin{array}{c}\text { Контрольна } \\
\text { група (n-135) }\end{array}$ \\
\hline Явно виражена депресивна симптоматика & $13,2 \%$ & $12,1 \%$ \\
\hline Легка депресія & $38,1 \%$ & $37,1 \%$ \\
\hline Без депресивний стан & $48,7 \%$ & $50,8 \%$ \\
\hline
\end{tabular}

Результати проведеного дослідження диференціальної діагностики депресивних станів і станів, близьких до депресії у комбатантів, учасників бойових дій, продемонстрували наявність великої кількості комба- 
тантів 3 високим проявом даних станів, що в свою чергу засвідчує те, що у продіагностованих респондентів спостерігався стан психічного дискомфорту та психологічної дезадаптованості до робочих навантажень. Ці комбатанти, для зниження інтенсивності депресивних станів, потребували психологічного розвантаження та зниження інтенсивності нервово-психічної напруженості, шляхом застосування до них когнітивноповедінкової терапії, арт-терапії, масажів, рекреаційної терапії тощо.

\section{6. Аналіз рівнів бойового досвіду та каналів психологічних ресурсів комбатантів}

На основі проведеної методики «Шкала оцінки інтенсивності бойового досвіду» ми мали змогу визначити рівень тривалості і інтенсивності стресової дії бойової обстановки на комбатантів. Дана шкала, дозволила виявити наступні результати: в експериментальній групі відсутність бойового досвіду простежувалася у $0,2 \%$ досліджуваних осіб, низький рівень бойового досвіду спостерігався у 12,1\% комбатантів, середній рівень бойового досвіду комбатантів був виявлений у 63,6\% досліджуваних, а високий рівень бойового досвіду був констатований у 24,1\% комбатантів.

В контрольній групі комбатантів, відсутність бойового досвіду простежувався у $2,1 \%$ досліджуваних осіб, низький рівень бойового досвіду спостерігався у 19,2\% комбатантів, середній рівень бойового досвіду комбатантів був виявлений у 59,6\% досліджуваних, а високий рівень бойового досвіду констатований у 19,1\% комбатантів.

Отримані результати дослідження комбатантів експериментальної та контрольної груп представлено у таблиці 9.

Таблиця 9

Результати дослідження комбатантів за шкалою оцінки інтенсивності бойового досвіду в експериментальній та контрольній групах

\begin{tabular}{|l|c|c|}
\hline \multicolumn{1}{|c|}{ Рівні бойового досвіду } & $\begin{array}{c}\text { Експериментальна } \\
\text { група (n-221) }\end{array}$ & $\begin{array}{c}\text { Контрольна група } \\
\text { (n-135) }\end{array}$ \\
\hline Відсутність бойового досвіду & $0,2 \%$ & $2,1 \%$ \\
\hline Низький рівень бойового досвіду & $12,1 \%$ & $19,2 \%$ \\
\hline Середній рівень бойового досвіду & $63,6 \%$ & $59,6 \%$ \\
\hline Високий рівень бойового досвіду & $24,1 \%$ & $19,1 \%$ \\
\hline
\end{tabular}


Отримані результати засвідчили, що велика кількість комбатантів мали середній та високий рівень бойового досвіду, а це в свою чергу говорить про те, що вони під час перебування у зоні АТО-ООС зазнали таких аспектів бойового досвіду комбатантів, як: перебування у бойових дозорах, участь у десантних операціях, виконання бойового завдання в умовах підвищеної небезпеки; знаходження в оточенні ворога; втрати людей у їх підрозділах яких було вбито, поранено або пропало без вісті; перебування в зоні обстрілу зі сторони противника; спостереження, за тим як хтось був вбитий або поранений; потрапляння у небезпеку бути вбитим або бути пораненим, потрапляння в пастки, та інші дуже небезпечні ситуації; перебування під прямим вогнем ворога; отримання поранення або інших фізичних ушкоджень під час бойових дій; отримання інвалідності внаслідок бойових дій.

Такі високі показники інтенсивності бойового досвіду, у комбатантів, свідчать про те, що дані військові отримати бойові психічні травми під час виконання ними своїх службових обов'язків. А це, в свою чергу, призводить до виникнення посттравматичного стресового розладу і інших супутніх психосоматичних порушень (захворювань) та можливої повторної психічної травматизації комбатанта, як під час бойових дій так і в мирний період його цивільного життя.

На основі проведеної методики BASIC Ph, ми мали змогу визначити 6 основних каналів, психологічних ресурсів комбатантів, кожен 3 яких «допомагає» вийти з кризової ситуації.

В процесі експериментального дослідження комбатантів було виявлено найбільш розвинуті канали психологічного ресурсу та ті канали які потребували найбільшого розвитку. У комбатантів експериментальної групи, серед каналів що добре розвинуті, ми спостерігали наступні результати: канал «В» - Базові цінності, виявився у 13,2\% осіб, канал « $\mathrm{S} »-$ Соціальний, спостерігався у 10,1\% досліджуваних комбатантів, канал «I»- Імагінація, уява, був констатований у 9,1\% осіб; канал «С» - Когнітивне мислення, був виявлений у 67,6\% комбатантів. Канал «А» - Афект та канал «Рh» - Фізіологія, не був виявлений у жодного з комбатантів.

У комбатантів контрольної групи, серед каналів що добре розвинуті, ми констатували наступні результати: канал «В»- Базові цінності, виявився у 12,1\% продіагностованих осіб, канал «S»- Соціальний, простежувався у 11,2\% досліджуваних, канал «I»- Імагінація, 
уява, спостерігається у 8,2\% респондентів; канал «С»- Когнітивне мислення, був виявлений у 68,5\% комбатантів. Канал «А»-Афект та канал «Рh» - Фізіологія, не був зафіксований у жодного з комбатантів.

А серед каналів що потребують найбільшого розвитку у комбатантів, експериментальної групи, було констатовано наступні діагностичні результати: канал «В»- Базові цінності, виявився у $12,1 \%$ респондентів, канал «А» - Афект, спостерігався у 46,6\% досліджуваних, канал «S»- Соціальний, простежувався у 11,1\% комбатантів, канал «І» - Імагінація, уява, констатований у 16,1\% досліджуваних осіб; канал «Рh»- Фізіологія, був виявлений у 14,1\% комбатантів. Канал «С»- Когнітивне мислення, у жодного з комбатантів не виявлено.

Серед каналів що потребують найбільшого розвитку у комбатантів контрольної групи, ми спостерігали такі результати, як: канал «В»-Базові цінності, був виявлений у $11,2 \%$ респондентів, канал «А»Афект, спостерігався у 49,5\% досліджуваних, канал « $\mathrm{S} »-$ Соціальний, простежувався у 10,1\% комбатантів, канал «I» - Імагінація, уява, був констатований у 14,1\% досліджуваних осіб; канал «Ph»- Фізіологія, виявився у 15,1\% комбатантів. Канал «С»- Когнітивне мислення, у жодного з комбатантів не виявлено.

Порівняльні результати експериментального дослідження стратегій поведінки комбатантів у психотравмуючих ситуаціях представлені у таблиці 10.

Таблиця 10

Результати дослідження комбатантів експериментальної та контрольної груп за методикою BASIC Ph

\begin{tabular}{|c|c|c|c|c|}
\hline \multirow{2}{*}{$\begin{array}{c}\text { Канали психологічного } \\
\text { ресурсу }\end{array}$} & \multicolumn{2}{|c|}{$\begin{array}{l}\text { Експериментальна } \\
\text { група (n-221) }\end{array}$} & \multicolumn{2}{|c|}{$\begin{array}{c}\text { Контрольна група } \\
\text { (n-135) }\end{array}$} \\
\hline & $\begin{array}{l}\text { Найбільш } \\
\text { розвинуті }\end{array}$ & $\begin{array}{l}\text { Потребують } \\
\text { розвитку }\end{array}$ & $\begin{array}{l}\text { Найбільш } \\
\text { розвинуті }\end{array}$ & $\begin{array}{c}\text { Потребують } \\
\text { розвитку }\end{array}$ \\
\hline «В»- Базові цінності & $13,2 \%$ & $12,1 \%$ & $12,1 \%$ & $11,2 \%$ \\
\hline «А»-Афект & $0 \%$ & $46,6 \%$ & $0 \%$ & $49,5 \%$ \\
\hline «S»-Соціальний & $10,1 \%$ & $11,1 \%$ & $11,2 \%$ & $10,1 \%$ \\
\hline «І»- Імагінація, уява & $9,1 \%$ & $16,1 \%$ & $8,2 \%$ & $14,1 \%$ \\
\hline «С»- Когнітивне мислення & $67,6 \%$ & $0 \%$ & $68,5 \%$ & $0 \%$ \\
\hline «Рh»- Фізіологія & $0 \%$ & $14,1 \%$ & $0 \%$ & $15,1 \%$ \\
\hline
\end{tabular}


Виходячи із отриманих результатів дослідження, ми можемо констатувати той факт, що у більшої частини комбатантів, найкраще розвинутий канал ресурсності «С». Це свідчить про те, що при подоланні кризових психотравмуючих ситуацій, психологічним ресурсом для даних комбатантів є їх переконання, розсудливість, реальність, логіка, планування, навчання, інформація, порядок їх пріоритетів та альтернатив. Даний канал психологічного ресурсу та адаптації комбатантів, направлений на використання когнітивних стратегії, таких, як: збір інформації, рішення проблем, самоорієнтація, внутрішній діалог або складання списків дій і переваг. Це допомагає комбатантам більш адекватного реагування на психотравмуючі ситуації як бойової обстановки так і цивільного життя.

Також, під час дослідження було виявлено, що у комбатантів недостатньо розвинуті такі канали ресурсу як «А» (афект), «І» (імагінація, уява) та «Рh» (фізіологія). Ці канали психологічного ресурсу та адаптації комбатантів, мінімально чи взагалі не використовуються ними при подоланні стресових ситуацій. В наслідок цього в них спостерігаються різноманітні труднощі (проблеми, захворювання) в емоційній, творчій та фізіологічній сфері їхнього життя.

\section{7. Висновки}

Підсумовуючи результати проведення першого «Початкового» етапу програми психологічного супроводу комбатантів, який передбачав діагностику віддалених наслідків стресогенних впливів у комбатантів та встановлення позитивного контакту з комбатантами які брали участь у програмі супроводу. Можемо зазначити, що під час проведення першого етапу програми (діагностичне дослідження), протягом 2018-2019 років, на базі військових частин, рекреаційних установ, соціальних, волонтерських та реабілітаційних центрів, психологічних наслідків участі комбатантів у бойових діях, було констатовано присутність (у значної кількості досліджуваних) таких явищ як: посттравматичний стресовий розлад, стрес, тривожність, депресія.

Тобто, отримані дані підтверджують, результати попередніх досліджень вітчизняних та закордонних науковців та практиків про те, що певна частина комбатантів які приймали участь у бойових діях з часом починають страждати від віддалених наслідків стресогенних впливів. 
I тому, ми вважаємо, що подальше впровадження програми психологічного супроводу комбатантів, з віддаленими наслідками стресогенних впливів, та їх сімей, на засадах генетико-психолог-аксіологічного підходу, а саме другого етапу «Надання психолого-соціальної допомоги або підтримки комбатантам та їх сім'ям», є перспективним та ефективним засобом психологічної реабілітації.

\section{Список літератури:}

1. Агаєв Н.А., Кокун О.М., Пішко I.О., Лозінська Н.С., Остапчук В.В., Ткаченко В.В. Збірник методик для діагностики негативних психічних станів військовослужбовців : Методичний посібник. Київ : НДЦ ГП ЗСУ, 2016. 234 с.

2. Водопьянова Н.Е. Психодиагностика стресса. Санк-Петербург : Питер, 2009. $336 \mathrm{c}$.

3. Мирошник О.Г., Нещетна К.А. Психологічні чинники конфліктної поведінки особистості : Методичні рекомендації для самостійної роботи. Полтава : Полтавський НПУ ім. В.Г. Короленка, 2012. 55 с.

4.Психологічна корекція посттравматичних стресових розладів : Навчально-методичний комплекс / укл. Л.М. Москалюк. Київ : Вид-во Національної академії внутрішніх справ, 2014. 38 с.

5. Райгородский Д.Я. Практическая психодиагностика. Методики и тесты. Москва : Бахрах-М, 2011. 672 с.

6. Щербатых Ю.В. Психология стресса. Москва : Изд-во Эксмо, 2005. 304 с.

7. Черепанова И.В., Черепанов О.А. Основы психологической помощи : курс лекций. Могилев : МГУ им. А.А. Кулешова, 2014. 304 с.

8. Beck, A.T., Epstein, N., Brown, G., \& Steer, R.A. An inventory for measuring clinical anxiety: Psychometric properties. Journal of Consulting and Clinical Psychology. 1988. Vol. 56(6). 893-897.

9. Weathers, F. W., Huska, J. A., \& Keane, T. M. The PTSD checklist military version (PCL-M). Boston, MA : National Center for PTSD, 1991.

\section{References:}

1. Aghajev N.A., Kokun O.M., Pishko I.O., Lozinsjka N.S., Ostapchuk V.V., Tkachenko V.V. (2016) Zbirnyk metodyk dlja diaghnostyky neghatyvnykh psykhichnykh staniv vijsjkovosluzhbovciv: Metodychnyj posibnyk [Collection of methods for diagnosing negative mental states of servicemen: Methodical manual]. Kyiv: NDC GhP ZSU. (in Ukrainian)

2. Vodop'yanova N.E. (2009) Psikhodiagnostika stressa [Psychodiagnostics of stress]. Sank-Peterburg: Piter. (in Russian)

3. Myroshnyk O.Gh., Neshhetna K.A. (2012) Psykhologhichni chynnyky konfliktnoji povedinky osobystosti: Metodychni rekomendaciji dlja samostijnoji roboty [Psychological factors personality conflict behavior: Guidelines for independent work]. Poltava: Poltavsjkyj NPU im. V.Gh. Korolenka. (in Ukrainian) 


\section{Roman Popeliushko}

4. Moskaljuk L.M. (ed.) (2014) Psykhologhichna korekcija posttravmatychnykh stresovykh rozladiv: Navchaljno-metodychnyj kompleks [Psychological correction of post-traumatic stress disorders: Educational and methodical complex]. Kyiv: Vyd-vo Nacionaljnoji akademiji vnutrishnikh sprav. (in Ukrainian)

5. Raygorodskiy D.Ya. (2011) Prakticheskaya psikhodiagnostika. Metodiki $i$ testy [Practical psychodiagnostics. Techniques and tests]. Moscow: Bakhrakh-M. (in Russian)

6. Shcherbatykh Yu.V. (2005) Psikhologiya stressa [Psychology of stress]. Moscow: Izd-vo Eksmo. (in Russian)

7. Cherepanova I.V., Cherepanov O.A. (2014) Osnovy psikhologicheskoy pomoshchi: kurs lektsiy [The basics of psychological assistance: a course of lectures]. Mogilev: MGU im. A.A. Kuleshova. (in Russian)

8. Beck, A.T., Epstein, N., Brown, G., \& Steer, R.A. (1988) An inventory for measuring clinical anxiety: Psychometric properties. Journal of Consulting and Clinical Psychology, vol. 56(6), pp. 893-897.

9. Weathers, F.W., Huska, J.A., \& Keane, T.M. (1991) The PTSD checklist military version $(P C L-M)$. Boston, MA: National Center for PTSD. 